\title{
Germanic Loanwords in Proto-Slavic
}

Saskia Pronk-Tiethoff: The Ger- hoff (henceforth GLPS and SPT, remanic Loanwords in Proto-Slav- spectively) is similarly based on her ic. (Leiden Studies in Indo-Eu- $\mathrm{PhD}$ thesis, The Germanic Loanropean 20.) Amsterdam-New words in Proto-Slavic: Origin and York: Editions Rodopi B. V. 2013. Accentuation, defended in Leiden $\mathrm{X}, 316 \mathrm{pp}$.

It has been 80 years since the Finnish Slavist Valentin Kiparsky defended his classic PhD thesis, Die gemeinslavischen Lehnwörter aus dem Germanischen (1934), which has thereafter been the standard reference work on the topic. Therefore, the book under review could hardly have been more welcome.

The Germanic Loanwords in Proto-Slavic by Saskia Pronk-Tietin November 2012. Although accentuation still plays a major role in GLPS, my review concentrates on Germanic-Slavic contacts in general, since Slavic accentology is beyond my scholarly expertise.

Chapter 1, called "Introduction" (pp. 5-29), already reveals that GLPS is a 21st century work unlike any of its predecessors, because SPT relies on the most up-to-date etymological dictionaries around, such as Rick Derksen's Etymological Dictionary 
of the Slavic Inherited Lexicon (2008) as well as Guus Kroonen's then still unpublished Etymological Dictionary of Proto-Germanic (2013). Incidentally, both Derksen and Kroonen used to be her Leiden colleagues together with many other outstanding etymologists, which is always an advantage for any beginning scholar.

As a matter of fact, Kiparsky's situation was similar, because his supervisors in Helsinki were no less than the Slavist J. J. Mikkola and the Germanicist T.E. Karsten, whose great achievements in loanword studies can in no way be denied in spite of both of their later close relations with Nazi Germany. In general, the fact that Finnish has so many loanword strata of different ages had already made Finland a superpower of loanword studies back in the 19 th century. Hence, it is no wonder that Kiparsky was methodologically superior to his contemporaries, basing his opinions on "sichere Lautgesetze" rather than "semasiologische und kulturhistorische Momente", the latter of which can too easily lead to circular reasoning.

As Chapters 2 and 3 are aptly described by their titles, "The ProtoSlavic prosodic system" (pp. 31-38) and "Research history on the accentuation of Germanic loanwords in Proto-Slavic" (pp. 39-49), I may move on to Chapter 4, called "Language contact between Proto-Slavic and Germanic tribes" (pp. 51-76), which is no doubt the most interesting chapter for non-linguistic readers, pithily discussing the extralinguistic background of Germanic-Slavic contacts. As far as the Germanic and Slavic homelands are concerned, SPT frequently cites the onomastic studies by Jürgen Udolph, who, however, has more recently been under attack for his ultra-conservative views on IndoEuropean linguistics (e.g. Harald Bichlmeier in Acta Linguistica Lithuanica 66 [2012], 68 [2013]), something that SPT could not have known at the time when she wrote her thesis. Anyway, any linguistic homeland stands and falls with the linguistic evidence backing it.

As SPT correctly points out, the fact that Proto-Slavic has no maritime terminology suggests that the Slavic homeland was nowhere near the coast (pp. 6o-61). As the ProtoGermanic maritime terminology in turn could hardly be more extensive, Udolph's Germanic homeland in Thuringia and the adjacent areas in Lower Saxony and Saxony-Anhalt is too far inland, not to mention that it also fails to explain the hundreds of Germanic loanwords in both Proto-Finnic and Proto-Saami, especially considering that Proto-Germanic has only a few borrowings from Celtic, which was spoken much closer to his pro- 
posed homeland. Incidentally, there are many more Celtic loanwords in Gothic, suggesting that Gothic was the southernmost Germanic branch rather than the easternmost (p. 56). At least if the traditional idea of the Gothic homeland in the Lower Vistula area were correct, one would expect considerably more Gothic loanwords in Baltic, for instance.

In my view, the core area of the Germanic proto-language was more likely Denmark, which as early as the Nordic Bronze Age (ca. 1700-500 BC) had archaeologically demonstrable nautical connections as far as the Finnic and Saami homelands in Estonia and Finland (respectively?). As a matter of fact, the Germanic migrations might even, at least in part, have been caused by the rising sea level, which even today causes problems in the North Sea area. Still, an even more important reason was evidently the fact that global climate conditions became both cooler and dryer during the Migration Period (ca. 300$700 \mathrm{AD}$ ), something that made the Roman and Byzantine empires even more tempting than they would have been otherwise. In any case, the Germanic migrations finally led to the earliest Germanic-Slavic contacts somewhere in Eastern Europe.

Chapter 5 titled "The main corpus: Germanic loanwords in ProtoSlavic" (pp. 77-167) can be consid- ered the core of GLPS, extensively discussing " 76 words that can be regarded as Germanic loanwords in Proto-Slavic". Interestingly, quite a number of these were also borrowed into Finnic either directly or through Slavic. Below I first list all of the Germanic loanwords parallelly borrowed into Slavic (GLPS) and Finnic (A.D. Kylstra \& al., Lexikon der älteren germanischen Lehnwörter in den ostseefinnischen Sprachen [1991, 1996, 2012]):

Germanic *arkō- 'box, chest, ark' $\rightarrow$ Slavic *orky 'box'; Finnic *arkku 'box, chest, coffin'.

Germanic *beuda- 'plate, table' $\rightarrow$ Slavic *bljudo 'plate, dish'; Finnic *peütä 'table'.

Germanic ^dōm(j)a- 'judgment, verdict' $\rightarrow$ Slavic ${ }^{*}$ duma 'advice, thought, opinion'; Finnic *toomijo 'judgment, verdict?'

Germanic *hansō- 'band of warriors, cohort' $\rightarrow$ Slavic *xosa 'robbery, trap'; Finnic *kansa 'people, nation'.

Germanic *hlaiba- 'loaf, bread' $\rightarrow$ Slavic *xlébs 'loaf, bread'; Finnic *laipa 'loaf, bread' (N. B. the vocalism of Finnish leipä is secondary, as shown by Leivu South Estonian laib and Salaca Livonian laibe).

Germanic *hlewa- 'cover (against the weather)' $\rightarrow$ Slavic ${ }^{*}$ xlěvo 'cattle shed, stable'; Finnic *lëvo 'roof, loft'.

Germanic *katila- 'kettle' $\rightarrow$ Slavic ${ }^{\star} k o t b l o$ 'kettle'; Finnic ${ }^{\star} k a t t i l a ~ ' k e t t l e$. 
Germanic *kaupjan- 'to buy, trade' $\rightarrow$ Slavic ${ }^{\star} k u p i t i$ 'to buy'; Finnic ${ }^{\star} k a u p-$ $p V$ - 'to trade'.

Germanic *kuninga- 'king, ruler' $\rightarrow$ Slavic ${ }^{\star} k$ żnędźb 'prince, ruler'; Finnic ${ }^{\star} k u$ ningas 'king'.

Germanic *laugō- 'bath, lye' $\rightarrow$ Slavic *lugz 'lye, caustic soda'; Finnic *lau(k)ka 'brine, pickle', *lauko(vesi) 'washing (water)'.

Germanic *lauka- 'Allium, onion' $\rightarrow$ Slavic *luks 'chive, onion'; Finnic *laukka 'Allium, onion'.

Germanic *naba-gaiza- 'auger, drill' $\rightarrow$ Slavic ${ }^{*}$ nebozězz /*nabozězъ 'wood drill'; Finnic *napakaira 'large drill'.

Germanic *nauta- 'cattle' $\rightarrow$ Slavic * nuta 'cow, cattle'; Finnic *nauta 'cattle'.

Germanic *skauta- '(hem of a) skirt, coattail' $\rightarrow$ Slavic ${ }^{\star}$ skutz 'hem, clothing covering the legs'; Finnic ${ }^{\star} k a u t a$ 'footlet (of a sock)'.

Germanic *winan- 'wine' $\rightarrow$ Slavic *vino 'wine'; Finnic *viina 'spirits, liquor'.

Note that the list above would have been even more extensive if I had included all of the more recent borrowings into Finnic from Old East Norse, Old Swedish, Old Gutnish, Middle Low German, etc. In addition to all of these direct Germanic loanwords in Finnic, there are also those mediated by Slavic (see Jalo Kalima, Slaavilaisperäinen sanastomme [1952], translated into German as Die slavischen Lehnwörter im Ostseefinnischen [1956]):
Germanic *hlewa- 'cover (against the weather)' $\rightarrow$ Slavic ${ }^{\star} x l e \check{v} v$ 'cattle shed, stable' $\rightarrow$ Finnic *läävä 'cattle shed' (cf. Finnic *lëvo above).

Germanic ‘papa- 'clergyman, priest' $\rightarrow$ Slavic ${ }^{\star}$ pops 'clergyman, (Orthodox) priest' $\rightarrow$ Finnic *pappi 'clergyman, priest'.

Gothic Xristus, Old High German Christ, etc. 'Christ' $\rightarrow$ Slavic ${ }^{*} x r b s t z /{ }^{*} k r b s t z$ 'cross, Christ, baptism' $\rightarrow$ Finnic ${ }^{*}$ risti 'cross'.

As we can see, some words seem to be more expansive than others, especially because many of the Germanic sources above were already borrowings from Latin or Greek. In fact, it is not always easy to distinguish the direct Latin loanwords in Slavic from those mediated by Germanic, as discussed in detail in Chapter 6, titled "Words that cannot be regarded as certain Germanic loanwords in Proto-Slavic" (pp. 169-215). For instance, Slavic *jbstrba '(heated) room' is one of those cases in which SPT leaves the question open as to whether its ultimate source was Vulgar Latin *extūfa 'steam bath' or Germanic ${ }^{*}$ stubo - 'heated room', the latter of which was at least the source of Finnic *tupa '(heated) room'.

Chapter 6 also gives other reasons why certain earlier suggested cases "cannot be regarded as certain Germanic loanwords in Proto- 
Slavic". First of all, some words simply do not go back to Proto-Slavic, although there is nothing wrong with their Germanic loan etymologies. On the other hand, there are also cases where borrowing from Germanic seems less likely than inheritance from Indo-European. For instance, both Germanic *leuda'people' and Slavic *ljudz 'people' evidently go back to Indo-European ${ }^{\star} h_{1}$ leud-o-, even though Finnic *liuta 'crowd' must still be considered a (North) Germanic loanword. Similarly, both Germanic *barda'beard' and Slavic ^borda 'beard, chin, throat' are of Northwest IndoEuropean inheritance, whereas this time Finnic *parta 'beard' could in theory have been borrowed from Germanic, Slavic or even Baltic.

The most interesting example is, after all, Slavic ${ }^{\star} m e c ̌ b /{ }^{*} m b c ̌ b$ 'sword'. As SPT convincingly argues, it could be neither a borrowing from nor a cognate of Germanic ${ }^{\star} m \bar{e} k$ kja'sword', and while the latter was indeed the source of Finnic ${ }^{{ }^{*}}$ mëekka 'sword', the Slavic and Germanic words have no further etymologies apart from some similar words in Iranian and Caucasian, suggesting that we are dealing with a relatively recent Wanderwort (pp. 210-211). As far as Finnic *mëëkka is concerned, it cannot be connected with the earliest Bronze-Age swords, because as I recently argued elsewhere ("The
Prehistoric Germanic Loanword Strata in Finnic" in Riho Grünthal \& Petri Kallio (eds): A Linguistic Map of Prehistoric Northern Europe [2012]), no Finnic word with a long vowel followed by a geminate consonant and an $a$-stem can date back beyond the Late Proto-Finnic stage roughly coinciding with the Early Runic period (ca. 200-500 AD).

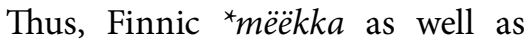
Slavic ${ }^{*} m e \check{c} b /{ }^{*} m b \check{c} b$ and Germanic ${ }^{\star} m_{1} \bar{e}_{1} k j a$ - much more likely referred to some newer Iron-Age sword type.

Chapter 7, called "The origin of the loanwords” (pp. 217-255), draws conclusions based on the data in Chapter 5. SPT essentially follows the footsteps of Kiparsky by using phonology as the basis of her stratification. Still, she also concludes that all the Germanic loanwords in Proto-Slavic are either Gothic or West Germanic, thus rejecting Kiparsky's idea of the Proto-Germanic loanword stratum, something that was in fact a misnomer from the beginning, since even he himself dated this stratum to the first few centuries AD, when Proto-Germanic was no longer spoken, as confirmed by runic evidence, for instance. On the other hand, SPT simultaneously rehabilitates Kiparsky's idea of the West Germanic loanword stratum which has repeatedly been questioned for being too late to go back to the Proto-Slavic stage. 
In addition to phonology, Chapter 7 also deals with morphology and semantics. As far as the former is concerned, it is interesting that the Germanic verbal prefix ${ }^{*} g a$ - was sometimes borrowed into Slavic (cf. Germanic ${ }^{\star} g a-n a z j a n$ - 'to save, guard' $\rightarrow$ Slavic *gonoziti 'to save'), because it was never borrowed into Finnic in spite of its many more Germanic loanwords. Yet in my opinion, it is even more interesting to compare the semantic categories of the Germanic loanwords in Slavic to those in Finnic. Most of the categories listed by SPT are well represented in Slavic and Finnic, such as "power and warfare", "skills and mental concepts", "technical terminology", "trade" and "yard and home grown/made products" (pp. 251-255). However, there is one striking exception, namely "Christian terminology", which was not borrowed into Finnic directly from Germanic but through Slavic (cf.
Finnic ${ }^{\star}$ pappi and ${ }^{\star}$ risti above).

As I noted earlier, I am not familiar enough with Slavic accentology to be in a position to evaluate Chapter 8, titled "Accentological analysis of the material" (pp. 257273), which is also the last actual chapter of GLPS, followed only by "Bibliography" (pp. 275-290) as well as "Index" (pp. 291-316). As someone who is more familiar with loanword studies, I can say that GLPS will finally supplant Kiparsky's 8o-year-old $\mathrm{PhD}$ thesis as the standard reference work on Germanic-Slavic contacts, not that there would be no room for further studies. On the contrary, I sincerely hope that GLPS is only the start of a more loanword-friendly atmosphere among Indo-Europeanists, many of whom have so far favoured language-internal explanations whenever possible.

Petri Kallio 